\title{
Development of Khoa by Utilization of Milk Solids in Semi-Automatic Machine
}

\author{
Vaquil", P.K. Bhardwaj, Rekha Devi, Surender Kumar and S.S. Ahlawat \\ Department of Livestock Products Technology, College of Veterinary Sciences, Lala Lajpat \\ Rai University of Veterinary and Animal Sciences, Hisar, Haryana, India \\ *Corresponding author
}

\section{A B S T R A C T}

\begin{tabular}{|l|}
\hline K e y w o r d s \\
$\begin{array}{l}\text { Skim milk Khoa (SMP), } \\
\text { cream (50\% fat), Ghee, } \\
\text { Whey protein } \\
\text { concentrate, Semi- } \\
\text { automatic machine, } \\
\text { Homogenization and } \\
\text { sensory attributes }\end{array}$ \\
\hline Article Info \\
\hline $\begin{array}{l}\text { Accepted: } \\
\text { 20 July } 2018 \\
\text { Available Online: } \\
\text { 10 August } 2018\end{array}$ \\
\hline \hline
\end{tabular}

The present study was undertaken for utilization of milk solids for development of khoa by semi-automatic machine. Skim milk powder, cream (50\% fat) and ghee were used for khoa preparation. To meet legal requirement of fat standardization was done by Pearson square method. Different combination of homogenization stages and type of desiccation machine were prepared. Three different levels $(0.3 \%, 0.4 \%$ and $0.5 \%)$ of whey protein concentrate were incorporated to improve texture of skim milk powder (SMP) and ghee khoa. Selection of khoa from different milk solids were done on sensory basis. There were significant increases in sensory attributes of khoa after addition of whey protein. Finally double satge homogenized and gas cooked khoa were selected from SMP and cream as well as SMP and ghee with $0.4 \%$ whey protein concentrate. Moisture contents of all khoa samples were statistically similar. Fat content of control khoa was significantly higher than $\mathrm{T} 1$ and T2. But protein content of T2 was significantly higher than T1 and control khoa. Ash content of T2 was found significantly higher as compared to control and T1. It was concluded than milk solids can be used successfully for development of khoa comparable to control in sensory attributes.

\section{Introduction}

The demand for milk and milk products in India is increasing rapidly due to growth in population, changes in demographic pattern, improvement in socio-economic status, and preferences of people. In order to meet the growing demand of milk and milk products, India has made significant progress in milk production and has emerged as the highest milk producing country in the world. India's annual milk production during 2016-17 was 165.4 million tonnes (DAHDF, 2018).
According to Prasad et al., (2012), approx. $50 \%$ of the total milk produced is converted to various traditional dairy products. Traditional dairy products have great commercial significance as they account for over $90 \%$ of all dairy products consumed in the country (Aneja et al., 2002).

Khoa is a major intermediate base for a variety of sweets like burfi, peda, kalakand, gulabjamun etc. (Soumya et al., 2015). About six lakh tonnes of khoa are being manufactured annually, mostly in private and 
unorganized sectors of India by utilizing about $7 \%$ of the total milk produced (Kumar, 2013). Demand of khoa is very high throughout year but due to the regional and seasonal imbalances in milk production in India, milk is not always available in sufficient quantity for khoa. Since, occasionally dairy plants in India have surplus dry milk and that lot of milk powder is available on competitive prices in the international markets. So to fulfill the demands of khoa there should be suitable technology for efficient use of surplus milk solids. Search for alternate sources of milk solids for modernization and industrial production of indigenous milk products seems to be a promising approach. Voghra and Rajorhia (1983) utilized the whole milk powder for preparation of khoa. So the present study is proposed for the proper utilization of milk solids for preparation of khoa.

\section{Materials and Methods}

\section{Procurement of raw materials}

Ghee, cream (50\% fat) and full cream buffalo milk (6\% fat) were procured from experimental dairy plant, Department of LPT, LUVAS, Hisar. Skim milk powder and whey protein concentrate were procured from local market of Hisar.

\section{Preparation of khoa using milk solids}

\section{Standardization}

Khoa was standardized for fat by Pearson's square method as per described by De, (2004). Standardization was done to meet legal standard of fat (20\% fat on fresh basis and $30 \%$ fat on dry basis).

\section{Preparation of khoa using milk solids}

Two type of khoa samples were prepared by using milk solids. First type by using skim milk powder and ghee and second type by using skim milk powder and cream (50\% fat). Level of whey protein concentrate $(0.3 \%$, $0.4 \%$ and $0.5 \%$ ) was selected based on preliminary sensory trials to improve the texture in ghee based khoa. For first type khoa, 680g SMP, 300g ghee and selected level of whey protein concentrate were mixed and add hot water to make total weight $5 \mathrm{~kg}$. Similarly for second type khoa, 500g SMP and $480 \mathrm{~g}$ cream were mixed and add hot water to make total weight $5 \mathrm{~kg}$ without any addition of whey protein concentrate. After proper mixing filtration was done followed by preheating up to $65^{\circ} \mathrm{C}$. Then homogenization (single stage and double stage) and desiccation in semiautomatic machine (gas operated and steam operated). So depending on homogenization stage and desiccation four combinations was prepared from each mixture. Selection of final products was done on basis of sensory score.

\section{Preparation of khoa from milk}

Control khoa sample was prepared using full cream buffalo milk in gas operated semiautomatic machine.

\section{Analysis}

\section{Sensory evaluation}

Khoa samples were evaluated for various sensory attributes viz. colour, body and texture, flavour and overall acceptability by a penal of eight to ten trained judges by 9 points hedonic scale (Nelson and Trout, 1964).

\section{Proximate composition}

Moisture, fat, protein and ash were estimated as per the method of AOAC (2005). Moisture content was measured by using drying oven method. Fat content was estimated by using soxhlets fat extraction apparatus. Protein 
content was estimated by the Micro kjeldahl method.

\section{Statistical analysis}

Results were statistical analyzed for analysis of variance (ANOVA) using SPSS 16 for Windows as per standard methods (Snedecor and Cochran, 1994). Duncan's multiple range test at $5 \%$ significance level was applied to find out significant differences in mean and results were expressed as mean \pm standard error.

\section{Results and Discussion}

\section{Standardization of whey protein concentrate}

The sensory parameter scores of control khoa sample were found significantly higher from khoa prepared from skim milk powder and ghee without incorporation of whey protein but after addition of $0.4 \%$ and $0.5 \%$ level of whey protein concentrate the overall acceptability score of these treatments were observed statistically similar to control khoa sample (Table 1). Patel et al., (1993) also reported that the incorporation of whey protein concetrate in khoa showed improved sensory characteristics over the control khoa. So on basis of sensory score and keeping in view the cost of production, $0.4 \%$ level of whey protein was selected for incorporation in khoa prepared from skim milk powder and ghee.

Standardization of homogenization and desiccation for khoa prepared from skim milk powder and ghee with incorporation of $0.4 \%$ whey protein concentrate

The sensory scores of double stage homogenized and gas operated machine desiccated khoa were found comparable to the control khoa sample (Table 2). So this treatment was selected for final study from skim milk powder and ghee along with $0.4 \%$ whey protein concentrate. Although the sensory scores of single stage were also statistically similar to control but depending on higher overall acceptability score double stage was selected because homogenization improve the texture of dairy products. Prakash and Sharma (1984) have observed that homogenization brings about reduction in size of fat globules which are less affected by heating and scraping during khoa preparation.

Sensory score for standardization of khoa prepared from skim milk powder and cream

By using skim milk powder and cream four different combinations were prepared depending on the stage of homogenization and type of desiccation. Sensory scores of double stage homogenized and gas cooked khoa were reported to comparable to control khoa sample (Table 3). But Vogra and Rajoria (1983) found lower sensory scores when they utilized whole milk powder for khoa production. It might be due to no homogenization in their study. Patrignani et al., (2007) and Mulay and Ladkani (1973) reported that homogenization significantly influence the texture of dairy products. So depending upon the overall acceptability score of treatment this treatment was selected for final study.

\section{Comparison of selected and standardized khoa}

Sensory scores of khoa samples which were prepared from milk solids were found comparable to control sample (Table 4). However lowest value of colour and appearance, body and texture, flavour and overall acceptability were reported in khoa prepared using skim milk powder and ghee (Table 4). Vogra and Rajoria (1983) also reported lower but comparable score of whole milk khoa. 
Table.1 Standardization of whey protein in khoa from skim milk powder and ghee (Mean \pm S.E., $n=18)$

\begin{tabular}{|c|c|c|c|c|c|}
\hline & \multicolumn{4}{|c|}{ Sample } \\
Parameter & $\mathbf{C}$ & $\mathbf{W P}_{\mathbf{0}}$ & $\mathbf{W P}_{\mathbf{1}}$ & $\mathbf{W P}_{\mathbf{2}}$ & $\mathbf{W P}_{\mathbf{3}}$ \\
\hline Colour and appearance & $8.50 \pm 0.23^{\mathrm{A}}$ & $7.75 \pm 0.25^{\mathrm{B}}$ & $7.83 \pm 0.24^{\mathrm{AB}}$ & $8.33 \pm 0.25^{\mathrm{AB}}$ & $8.17 \pm 0.24^{\mathrm{AB}}$ \\
\hline Body and texture & $8.42 \pm 0.15^{\mathrm{A}}$ & $6.08 \pm 0.26^{\mathrm{C}}$ & $7.33 \pm 0.28^{\mathrm{B}}$ & $8.17 \pm 0.24^{\mathrm{A}}$ & $8.25 \pm 0.25^{\mathrm{A}}$ \\
\hline Flavour & $8.33 \pm 0.14^{\mathrm{A}}$ & $7.08 \pm 0.19^{\mathrm{B}}$ & $7.50 \pm 0.20^{\mathrm{B}}$ & $8.25 \pm 0.22^{\mathrm{A}}$ & $8.17 \pm 0.24^{\mathrm{A}}$ \\
\hline Overall acceptability & $8.42 \pm 0.19^{\mathrm{A}}$ & $6.92 \pm 0.18^{\mathrm{B}}$ & $7.33 \pm 0.14^{\mathrm{B}}$ & $8.25 \pm 0.19^{\mathrm{A}}$ & $8.25 \pm 0.22^{\mathrm{A}}$ \\
\hline
\end{tabular}

Means with different capital letter superscripts in row differ significantly $(\mathrm{P} \leq 0.05)$. C-control khoa from full cream milk, $\mathrm{WP}_{0^{-}} \mathrm{SMP}$ and ghee khoa without whey protein concentrate, $\mathrm{WP}_{1^{-}}$with $0.3 \%$ Whey protein concentrate, $\mathrm{WP}_{2^{-}}$ with $0.4 \%$ whey protein concentrate, $\mathrm{WP}_{3}$-with $0.5 \%$ whey protein concentrate

Table.2 Standardization of khoa prepared from skim milk powder and ghee

\begin{tabular}{|c|c|c|c|c|c|}
\hline & \multicolumn{5}{|c}{ Sample } \\
\hline Parameter & Control & $\mathbf{G H}_{\mathbf{1}} \mathbf{g}$ & $\mathbf{G H}_{2} \mathbf{g}$ & $\mathbf{G H}_{\mathbf{1}} \mathbf{S}$ & $\mathbf{G H}_{2} \mathbf{S}$ \\
\hline Colour and appearance & $8.33 \pm 0.33^{\mathrm{A}}$ & $7.92 \pm 0.33^{\mathrm{AB}}$ & $8.16 \pm 0.31^{\mathrm{A}}$ & $7.00 \pm 0.37^{\mathrm{B}}$ & $7.17 \pm 0.31^{\mathrm{B}}$ \\
\hline Body and texture & $8.25 \pm 0.31^{\mathrm{A}}$ & $7.83 \pm 0.26^{\mathrm{AB}}$ & $8.00 \pm 0.22^{\mathrm{A}}$ & $7.50 \pm 0.34^{\mathrm{B}}$ & $7.67 \pm 0.34^{\mathrm{AB}}$ \\
\hline Flavour & $8.50 \pm 0.34^{\mathrm{A}}$ & $8.08 \pm 0.34^{\mathrm{A}}$ & $8.17 \pm 0.26^{\mathrm{A}}$ & $7.17 \pm 0.40^{\mathrm{B}}$ & $7.33 \pm 0.34^{\mathrm{B}}$ \\
\hline Overall acceptability & $8.42 \pm 0.22^{\mathrm{A}}$ & $8.00 \pm 0.31^{\mathrm{A}}$ & $8.24 \pm 0.31^{\mathrm{A}}$ & $7.00 \pm 0.26^{\mathrm{B}}$ & $7.50 \pm 0.21^{\mathrm{B}}$ \\
\hline
\end{tabular}

Means with different capital letter superscripts in row differ significantly $(\mathrm{P} \leq 0.05)$.Control- khoa from Full cream milk, $\mathrm{GH}_{1} \mathrm{~g}$ - SMP and ghee khoa with single stage homogenized and gas cooked, $\mathrm{GH}_{2} \mathrm{~g}-\mathrm{SMP}$ and ghee khoa with double stage homogenized and gas cooked, $\mathrm{GH}_{1} \mathrm{~s}-\mathrm{SMP}$ and ghee khoa with single stage homogenized and steam cooked, $\mathrm{GH}_{2} \mathrm{~S}$ - SMP and ghee khoa with double stage homogenized and steam cooked.

Table.3 Standardization of khoa prepared from skim milk powder and cream

\begin{tabular}{|c|c|c|c|c|c|}
\hline \multirow{2}{*}{ Parameter } & \multicolumn{4}{|c|}{ Sample } \\
\hline Colour and appearance & Control & $\mathbf{C H}_{\mathbf{1}} \mathbf{g}$ & $\mathbf{C H}_{\mathbf{2}} \mathbf{g}$ & $\mathbf{C H}_{\mathbf{1}} \mathbf{S}$ & $\mathbf{C H}_{\mathbf{2}} \mathbf{S}$ \\
\hline Body and texture & $8.33 \pm 0.21^{\mathrm{A}}$ & $8.00 \pm 0.26^{\mathrm{AB}}$ & $8.17 \pm 0.17^{\mathrm{AB}}$ & $7.17 \pm 0.31^{\mathrm{C}}$ & $7.50 \pm 0.22^{\mathrm{B}}$ \\
\hline Flavour & $8.50 \pm 0.27^{\mathrm{A}}$ & $7.67 \pm 0.33^{\mathrm{A}}$ & $8.00 \pm 0.26^{\mathrm{A}}$ & $7.67 \pm 0.33^{\mathrm{A}}$ & $7.83 \pm 0.31^{\mathrm{A}}$ \\
\hline Overall acceptability & $8.33 \pm 0.33^{\mathrm{A}}$ & $7.50 \pm 0.37^{\mathrm{A}}$ & $8.25 \pm 0.31^{\mathrm{A}}$ & $7.50 \pm 0.34^{\mathrm{AB}}$ & $7.67 \pm 0.63^{\mathrm{A}}$ \\
\hline & $8.17 \pm 0.21^{\mathrm{A}}$ & $7.17 \pm 0.17^{\mathrm{B}}$ & $7.33 \pm 0.21^{\mathrm{B}}$ \\
\hline
\end{tabular}

Means with different capital letter superscripts in row differ significantly $(\mathrm{P} \leq 0.05)$. Control- khoa from full cream milk, $\mathrm{CH}_{1} \mathrm{~g}$ - SMP and cream khoa with single stage homogenized and gas cooked, $\mathrm{CH}_{2} \mathrm{~g}-\mathrm{SMP}$ and cream khoa with double stage homogenized and gas cooked, $\mathrm{CH}_{1} \mathrm{~S}-\mathrm{SMP}$ and cream khoa with single stage homogenized and steam cooked, $\mathrm{CH}_{2} \mathrm{~s}-\mathrm{SMP}$ and cream khoa with double stage homogenized and steam cooked.

Table.4 Sensory evaluation of khoa (Mean \pm S.E., $n=18)$

\begin{tabular}{|c|c|c|c|}
\hline & \multicolumn{3}{|c|}{ Sample } \\
\hline & Control & T1 & T2 \\
\hline Colour and appearance & $8.50 \pm 0.23^{\mathrm{A}}$ & $8.42 \pm 0.19^{\mathrm{A}}$ & $8.17 \pm 0.18^{\mathrm{A}}$ \\
\hline Body and texture & $8.42 \pm 0.17^{\mathrm{A}}$ & $8.33 \pm 0.14^{\mathrm{A}}$ & $8.17 \pm 0.26^{\mathrm{A}}$ \\
\hline Flavour & $8.33 \pm 0.19^{\mathrm{A}}$ & $8.25 \pm 0.22^{\mathrm{A}}$ & $8.08 \pm 0.31^{\mathrm{A}}$ \\
\hline Overall acceptability & $8.42 \pm 0.29^{\mathrm{A}}$ & $8.33 \pm 0.21^{\mathrm{A}}$ & $8.17 \pm 0.26^{\mathrm{A}}$ \\
\hline
\end{tabular}

Means with different capital letter superscripts in a row within differ significantly ( $\mathrm{P} \leq 0.05)$. Control- khoa from full cream milk, T1-khoa sample from SMP and cream, T2- khoa sample from SMP and ghee. 
Table.5 Proximate composition of khoa (Mean \pm S.E., $n=6)$

\begin{tabular}{|c|c|c|c|c|}
\hline Sample & Moisture\% & Fat\% & Protein \% & Ash\% \\
\hline Control & $34.43 \pm 0.36^{\mathrm{A}}$ & $23.10 \pm 0.21^{\mathrm{A}}$ & $18.71 \pm 0.40^{\mathrm{B}}$ & $2.75 \pm 0.16^{\mathrm{B}}$ \\
\hline $\mathrm{T} 1$ & $35.06 \pm 0.53^{\mathrm{A}}$ & $21.17 \pm 0.48^{\mathrm{B}}$ & $15.42 \pm 0.43^{\mathrm{C}}$ & $2.56 \pm 0.14^{\mathrm{B}}$ \\
\hline $\mathrm{T} 2$ & $33.98 \pm 0.29^{\mathrm{A}}$ & $20.96 \pm 0.31^{\mathrm{B}}$ & $21.84 \pm 0.45^{\mathrm{A}}$ & $3.74 \pm 0.22^{\mathrm{A}}$ \\
\hline
\end{tabular}

Means with different capital letter superscripts in a column within differ significantly ( $\mathrm{P} \leq 0.05)$.Control- khoa from full cream milk, T1-khoa sample from SMP and cream, T2- khoa sample from SMP and ghee.

\section{Proximate composition of developed khoa}

Fat per cent of control sample was significantly higher from skim milk powder and ghee khoa and skim milk powder and cream khoa (Table 5). This might be due to raw materials used for preparation of khoa from milk solids, which were standardized for same fat percentage.

However higher fat value of control might be due to fat percentage of raw material (full cream milk). Similar findings were reported by Beniwal et al., (2009a) when they prepared khoa from full cream milk (6\% fat) but Choudhary et al., (2016) reported higher fat content in khoa which might be due to higher fat percent (7.86) of buffalo milk used for khoa production and lower moisture content in khoa $(23.94 \%)$.

Skim milk powder and ghee khoa have the significantly highest values of protein and ash than the other khoa sample. This could be due to incorporation of whey protein concentrate protein in raw materials used for the preparation of khoa. Control khoa also have significantly higher value of protein than skim milk powder khoa. This might be due to the protein content of raw material of full cream milk.

It was concluded that milk solids could be utilized successfully for preparation of khoa which have comparable sensory quality to full cream buffalo milk khoa. Incorporation of whey protein resulted increase sensory quality of khoa.

\section{References}

Aneja, R.P., Mathur B.N., Chandan R.C. and Banerjee A.K. (2002). Technology of Indian Milk Products, Dairy India Publications Delhi, 122-125.

AOAC. (2005). Official Methods of Analysis, Association of Official Analytical chemists, 18th edition, Washington, DC.

Beniwal, B.S., Rai, D.C., Kapoor, C.M., and Bhardwaj, P.K. (2009a). Standardization of quality and quantity of milk for khoa making through a semi mechanized method. Indian J dairy sci., 62(4): 272-274.

Choudhary, S., Arora, S., Kumari, A., Narwa, L. V. and Sharma, V. (2016). Impact of developed acidity in milk and subsequent neutralization on changes in physico-chemical properties and oxidative stability of khoa. Indian $J$. Dairy Sci., 69(6): 665-675.

DAHDF (2018). Annual report, Department of Animal Husbandry, Dairying \& Fisheries, India.

De, S. (2004). Outlines of dairy technology, 19th edition, Oxford publishing Company, New Delhi.

Kumar, M. (2013). Up-Gradation of khoa Production and Preservation Technologies. Smriddhi-Asian J. Phys. Sci. Eng Technol., 3(1):1-6.

Muley, C.A. and Ladkani, B.G. (1973). Comparative assessment of quality of khoa and their products from homogenized and unhomogenized milk. J. Food Sci. Technol., 10(3): 110-112. 
Nelson, J.A. and Trout, G.M. (1964). Judging Dairy Porducts 4thEdn.Olson Publ. Co. Nilwankee. P. 296.

Patel, R.S., Gupta, V.K., Singh S. and Reuter, H. (1993). Effect of addition of whey protein concentrate on sensory and instron texture profile of khoa from cow milk. J. Food Sci. Tech., 30(1): 64-65.

Patrignani, F., Iucci, L., Lanciotti, R., Vallicelli, M., Maina, J. M., Holzapfel W.H. and Guerzoni M. (2007). Effect of high pressure homogenization, nonfat milk solids and milk fat on the technological performance of a functional strain for the production of probiotic fermented milks. J. Dairy Sci., 90: 4513-4523.

Prakash, S. and Sharma, R.S. (1984). Compositional and storage characteristics of khoa made from lactose hydrolysed buffalo milk. J.Food Sci. Technol., 21(2): 78-81.

Prasad, R., Jha, A. and Jha, A. (2012). Textural and sensory characteristics of market mamples of peda manufacture in Varanasi city of India. $J$ Dairying Foods Home Sci., 31(4): 239-243.

Snedecor, G.W. and Cochran, W.G. (1994). Statistical method, $8^{\text {th }}$ edition, Oxford and IBAS publishing Company Calcutta. 172-196.

Soumya, R., Indumathi, K.P., Arora, S., Sharma, V. and Singh, A.K. (2015). Detection of calcium based neutralizers in milk and milk products by AAS. $J$. Food Sci. Technol., 52(2): 1188-1193.

Vogra, V.R. and Rajorhia, G.S. (1983). Utilization of dried milk for khoa making. Asian J. Dairy Res., 2 (2): 113118.

\section{How to cite this article:}

Vaquil, P.K. Bhardwaj, Rekha Devi, Surender Kumar and Ahlawat, S.S. 2018. Development of Khoa by Utilization of Milk Solids in Semi-Automatic Machine. Int.J.Curr.Microbiol.App.Sci. 7(08): 3863-3868. doi: https://doi.org/10.20546/ijcmas.2018.708.396 